\title{
8 \\ The Cemetery Cult hides in plain sight
}

On 27 March 1954, Schwartz and Shargo had a profound shock. After eight months of work reconstructing the Noise, they suddenly discovered that they were in the midst of an event that in many respects appeared to be a re-enactment of the 1947 phenomenon they had regarded as over and done. They thought they had excellent rapport with Bunai people and that they were aware of the important events in villagers' lives. Now, they learned abruptly that they had been blind to the fact that Bunai village was in the throes of the most dramatic event since several Titan and Usiai villages had merged into one to pursue the New Way together some eight years before. In addition, they realised that they were witnessing, not the beginnings of a second cargo cult, but its climax, for it had begun in earnest more than a year before, in mid-1952.

Schwartz and Shargo had approached the subject of the Noise more cautiously than the subject of the Movement. The latter was out in the open and a matter of pride. Villagers did not try to hide the fact of the Noise and many were quite comfortable talking about it at length. But most gave the impression that the events of 1947 were an aberration in the development of the Movement that had left little or no trace. And yet, in some accounts of the Movement, Schwartz and Shargo heard the implication that the Noise in some way was the foundation of all major events since. They therefore tried to allow a picture of the Noise to emerge without much direct inquiry while they focused on topics that 
they assumed were less fraught. They would discover, however, that some Bunai people were also cautiously feeling their way towards speaking more candidly with the anthropologists.

Mead had picked up hints of lingering interest in cargo cults early in her stay in Pere. But she told Schwartz and Shargo she feared that if she pursued these some Pere people might take her interest as a validation of their desire to pursue the secret of the cargo. Mead wanted to encourage what she saw as the strengths of the Movement and she assumed correctly that people's perceptions of her opinions - and, to a lesser extent, those of Schwartz and Shargo-could influence them. But hints of lingering interest in cargo were stronger in Bunai. Schwartz and Shargo also learned that both the relatively few Pere people still strongly interested in a cargo cult and those who knew but disapproved of cult stirrings preferred to keep these things a secret from Mead. She had told Pere people that she was once more going to put their lives in front of the world and they did not want to be portrayed as cargo cultists. Of course, had a cargo cult dominated events in Pere during Mead's visit, she may well have decided not to write a book about it, given the intentions she shared with Schwartz before leaving for New Guinea: She wanted to write a success story.

Bunai villagers also kept Schwartz and Shargo from knowledge of the cult for eight months. Even the villagers to whom they were closest and those who spoke freely to them about the Noise kept mum about the current cult. People like Pita Tapo had given them uninhibited accounts of the Noise. But neither he nor others betrayed the fact that the ideas and hopes that had driven it were still thriving.

\section{Missing the big story}

On 29 November 1953, a young Bunai man, home from work on the Australian-owned copra plantation on nearby Ndropwa Island, mentioned to Schwartz that a group of young men were going to a big feast on Johnston Island. He told Schwartz there would be several days of gambling, dancing, and feasting on costly quantities of store-bought food. When Schwartz asked about the occasion for the feast the young man said only that it was for a dead man. Schwartz wanted to go, too, because he had never visited this tiny island many miles to the south, with its small Titan village. This also sounded like an event unlike any he had 
seen before. But the vigour of the attempt to dissuade him from tagging along, as was his wont, puzzled him. By this time, Schwartz had acquired his own outrigger canoe with outboard motor and a regular crew, so he could travel at will, weather permitting. But some of the young men insisted that his canoe was too small for the rough seas they were sure to encounter. Schwartz's older, more experienced crew members scoffed at this and they volunteered to take Schwartz to Johnston Island. Two other canoes from Bunai also went, one leaving before Schwartz and one after. A canoe from Pere, carrying the schoolteacher, Prenis Tjolai, and some of his male students, had gone a few days earlier.

After arriving on Johnston Island things became ever more curious. On the first night after their arrival, Schwartz found schoolboys from Pere and others of their age dancing to ukuleles. The dancing, which continued for the next few days, was different from any he had seen before in Manus. The boys danced as if it were a solemn duty. There was none of the usual joking or horseplay, none of the shouts from the musicians, no attempts to vary a monotonous repertoire of songs and dances. Schwartz set out to look for the village kaunsil, Kisakiu. ${ }^{1}$ Although one could walk around the entire island in about twenty minutes, Schwartz could find no sign of him. Wherever he asked for Kisakiu, people told Schwartz that he was on the other side of the island. He did locate the luluai, who told Schwartz that the feast was merely to celebrate completing a new graveyard. They had worked very hard on it and decided to call all their relatives from other Titan villages to celebrate with them.

Schwartz had no obvious reason to doubt this. He saw and photographed the new graveyard-in Tok Pisin, the matmat. It was very impressive by Manus standards. During the day, the sun reflected glaringly from a fresh cover of clean white coral sand. And the graveyard was laid out in a regular pattern, unlike the usual graveyards that grew as the need arose, without much thought for their shape. Each grave in the several perfect lines of graves was marked by a cross carved with the name of the deceased and some crosses bore a date of death. A fence painted with white lime, which would have to be constantly renewed as the rain washed it off, surrounded the matmat. A large wooden cross stood at each end of the rectangular enclosure.

1 Not to be confused with Kisakiu of Tawi. 
Two gates to the matmat stood side by side with a large wooden cross between them, each gate resembling the kind found in all New Way villages. His guides told Schwartz that if he wanted to go inside the enclosure he had to go in through the right gate and proceed around the graveyard counterclockwise before leaving by the left gate. A similar gate in good repair stood at the entrance to the village.

Schwartz attended church services and a meeting before leaving the island. Unlike the services and meetings he had attended in Bunai and Pere it looked like almost everyone on the island was there. Also, the meeting began with a half hour of singing and Schwartz noticed that the songs performed had been important in the ritualised New Way that followed the demise of the Noise in 1947.

Looking back, Schwartz can only marvel that he was so innocent that he did not at least suspect that he was visiting the very centre of a new cargo cult and witnessing a feast held to honour the cult's tutelary ghost. All the other visitors, including those from Pere and Bunai, had come to attend not only the feasting, dancing, and daylight meetings, but also the nightly seances, which they kept secret from Schwartz. He registered only that Johnston Island seemed to have preserved a distinctively ritualistic form of the early Movement. Two members of his canoe crew, John Kilepak and Johannes Lokes, knew exactly what was going on, and they had known for more than a year. Although they usually helped Schwartz energetically with his research, they didn't think he needed to know about this.

Schwartz saw for himself how much visitors from other villages admired the new Johnston Island graveyard and how they discussed building similar ones in their own villages. In Bunai, Tjamilo raised the subject in December 1953. He wanted to refurbish the old cemetery, which would involve cutting the coconut palms growing there. Samol, a Bunai leader, opposed the idea and Schwartz was surprised at the vehemence with which people debated this issue and how much some seemed to care about the coconut trees. Only later-again-did Schwartz realise that Samol was a staunch opponent of the cargo cult and, hence, of the cemetery plan. But Tjamilo and a few of his supporters cut the palms when Samol was out of the village and made plans to build a fence and gates. 
Only weeks later, Schwartz and Shargo stood on the beach in Pere, watching Mead's canoe ease into the distance, taking her to Lorengau on the first leg of her trip back home. As they watched, Schwartz noticed an old man of Bunai digging a skeleton out of the gravel near the water's edge. The old man told Schwartz that it was his brother's skeleton and he pointed out how well the wood smoke enveloping the skull when it had resided in a bowl in his house rafters had preserved it. Schwartz soon learned that Tjamilo had told people to gather the remains of the dead buried in scattered beach graves near the old villages and bring them to Bunai to bury in the existing Bunai cemetery, for the cemetery built to cult design still was not ready.

In Bunai a few days later, Tjamilo was ready for a formal reburial of the remains that people had gathered. They had collected eight skeletons, including the skeleton of Tjamilo's father. They had cleaned each one, wrapped it in new cotton cloth, and carefully arranged it in its own wooden box. People did not hesitate to show Schwartz the skulls and they seemed to exhibit no particular reverence when handling the bones. They were as interested as he was in examining the skulls closely and they spoke freely of the deceased. When everything was ready, Tjamilo formed a procession to march the length of the village, beginning at the church, passing through the Usiai section (only Titan people marched in the procession), and ending at the graveyard. All the participants, some 30 adults and as many children, were dressed in their best clothing. The leading marchers carried wooden crosses to place on each grave. The children carried decorative bunches of green leaves. Tjamilo carried the Australian flag. Before they started, Tjamilo told Schwartz that they were going to sing a song that he would not know, 'a song belonging to all black men'. They then sang 'John Brown's Body' all the way to the graveyard. Schwartz knew that many Manus people had learned it from the Americans during the war, as well as 'Lay That Pistol Down' and many others. But Tjamilo's group had imbued it with ritual significance. After a brief ceremony at the graveyard, the marchers drifted off to join the general exodus to Baluan for the Movement Christmas celebration there. 


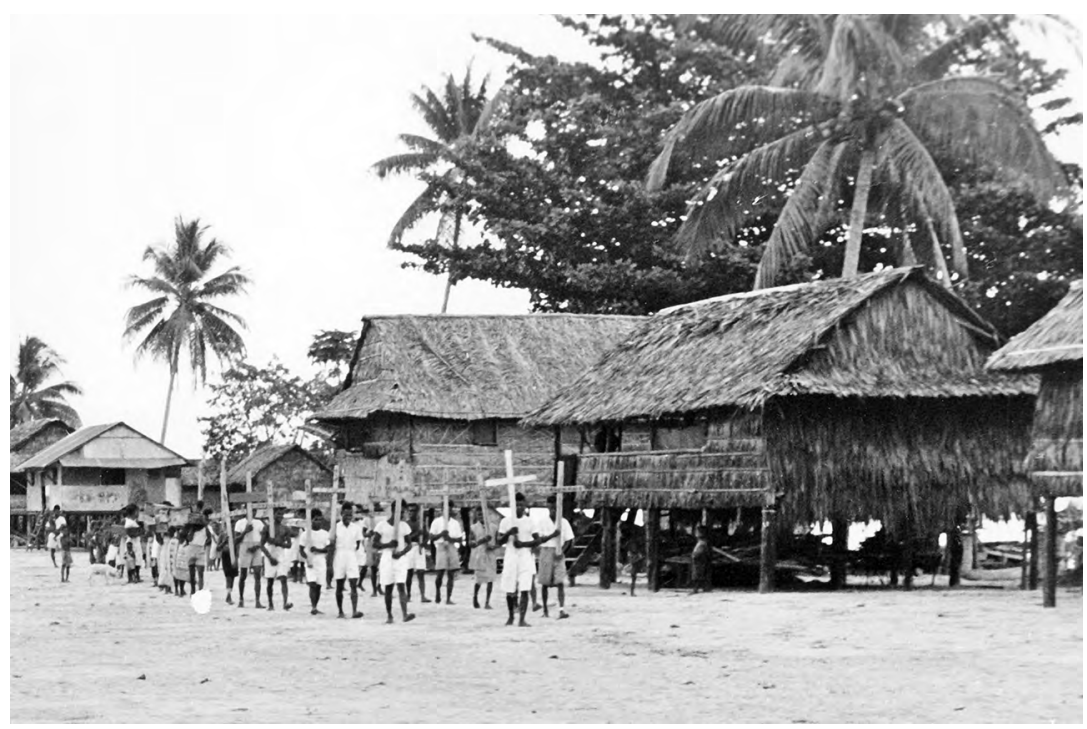

Figure 8.1: The procession to the old Bunai cemetery that Tjamilo organised in December 1953 to re-inter the remains of Cemetery Cult adherents' deceased kin.

Source: Theodore Schwartz. Digital copy courtesy of the Archive for Melanesian Anthropology, University of California, San Diego.

Schwartz and Shargo also went to Baluan for the Christmas events and it proved a turning point in their research. During 10 days there they began a close relationship with Paliau, who was happy to discuss the old Baluan culture, of which he had considerable knowledge, especially considering the amount of time he had spent escaping it as a youth. Finally, he dictated to Schwartz a marathon autobiography, talking continuously for almost 10 hours one night. In effect, Paliau had now accepted Schwartz as 'inside' (in Tok Pisin, insait) the Movement. He was to be allowed to attend all the meetings Paliau held with his leaders. Paliau also told the Movement leaders that he had told Schwartz everything during their all-night session and that there were no longer any secrets from him. The latter, however, was by no means true. Schwartz would find that Paliau had been quite selective.

Another event on Baluan during the Christmas visit would also affect Paliau's followers' perceptions of Schwartz and Shargo. One morning while the two walked along a dirt road to James and Marjorie Landman's house, they noticed a white man bathing in the shallow water near the beach. They said 'Good morning' and he answered. They thought little 
of it, although it was an odd place and time to find a European bathing. A boat carrying a party of Australian naval personnel sightseers had come to Baluan the day before. But when Schwartz and Shargo mentioned meeting the white bather to Landman he said that there shouldn't be any whites on the island at the moment other than his family, unless the man Schwartz and Shargo had seen had stayed overnight somewhere, which didn't seem likely. Landman sent the indigenous police constable to find the mystery European. The constable returned saying that he could find no signs of such a person but he had warned everyone to watch for him. Another boatload of sightseers arrived later but no one saw the bather again. Schwartz and Shargo dismissed the incident, assuming there was some simple natural explanation, even if they did not know what it was.

Villagers, however, continued to search and to speculate. Paliau suggested to Shargo that perhaps she had seen an angel. That evening several leaders from several villages proposed and acted on a new explanation. They decided that the man was from the Australian Air Force and had been sent to kill Schwartz and Shargo because they were now 'inside' the natives and the Australians were thus jealous and afraid of them. A guard of 10 Native Government Council councillors, carrying glaring and hissing kerosene pressure lamps, was posted around the house where Schwartz and Shargo were staying. Other men continued to search the island. Schwartz and Shargo protested, but not too vigorously, for they had learned that if they expressed even mild disapproval of anything related to the New Way no one would discuss it with them again.

By the next morning the exhausted men who had kept vigil through the night reported that they had seen no suspicious Europeans. But the idea persisted that Schwartz and Shargo had to be guarded and it resurfaced every time an Australian came to the village while they were there. (Baluan people did not, however, suspect the Landmans of designs on Schwartz and Shargo, for they knew and trusted them, at least to this extent.) Even a plane flying low over Baluan brought a few people to the anthropologists' defence. It was not until March, when the secrets of the cult were revealed to them, that Schwartz and Shargo learned that while they were on Baluan with a crowd of celebrants many others were spending Christmas on Johnston Island, about 10 miles away. There, in a seance held just before Christmas, the tutelary ghost of the cult had prophesied that Christ would appear on Baluan on Christmas day. When this news reached Baluan after Christmas the whole episode became clear. It was generally agreed that Schwartz and Shargo had been the only ones 
who had seen Christ and some assured them that had they been closer they would have seen the stigmata on his hands. Schwartz and Shargo, however, did not learn of this until after other events led them to much deeper knowledge of the cult.

On their return from Baluan, a number of Bunai people volunteered to talk to Schwartz and Shargo about the Noise. They had wanted to ask some Americans about it for a long time, they said, but they had been afraid to do so until Paliau had told them it was alright. A group of four men came every night for a week to dictate their stories: Tjamilo, Talimelion, Alphonse Kanawi, and Kisekup. These were the four Movement komiti from the Titan section of Bunai. They said that Tjamilo knew and remembered more about the Noise than anyone else. A succession of others followed, eager to tell their own stories.

Throughout this period of intensive research on the Noise, public meetings to discuss building a new cemetery in Bunai continued. A few younger men began to throw their support to Tjamilo, among them Pwatjumel, Samol's brother-in-law and usually his close supporter. Pwatjumel had had a dream in which he saw a graveyard set up as it should be. His drawing of it closely resembled the Johnston Island cemetery that he had heard about but not visited.

\section{Death and resurrection in Bunai}

Early in the morning on 26 February 1954, the son of Ponram, an old man of Yiru, an Usiai village not far from the beach, came to fetch Schwartz, saying that Ponram was dead. It wasn't clear whether he meant his father had merely lost consciousness or that he was deceased. The two sound very much alike in Tok Pisin. To say that someone has lost consciousness in Tok Pisin you say em $i$ dai. But to say someone is deceased you say em i dai finis. Ponram's son told Schwartz that his father had had violent convulsions, but now his body had died completely and he was limp and insensible. That is, in Tok Pisin, em i dai olgeta, which is still short of em $i$ dai finis. Schwartz hurried to the house where Ponram lay, thinking it must be a case of cerebral malaria. He'd already seen several cases, and each had resulted in death. Ponram was unconscious, saliva running from his mouth, when Schwartz arrived. The village native medical assistant (in Tok Pisin, the dokta boi: a local man who had received very basic paramedical training from the Australian administration) had just 
arrived and was administering intravenous quinine. Almost instantly Ponram began to show signs of life, making chewing motions with his mouth. Schwartz dismissed the idea of malaria when he determined that Ponram's temperature and pulse were normal. Someone put a betel nut in Ponram's mouth and he began to chew.

The house was crowded with people, but instead of looking relieved at Ponram's revival they seemed to be waiting for something more. One of his six adult sons was supporting Ponram in a semi-upright position. Several old men and women were grouped around him, among them his wife and Sayau Bombowai, the komiti from Katin. Ponram's eyes were open, staring vacantly and his tongue lolled out. No one spoke or wailed. Everyone stared at him intently. Occasionally he made protracted, empty aadaaa sounds, apparently involuntarily. His body looked relaxed. He made sudden, random, but not spasmodic movements. His muscle tone seemed normal. Ponram made a motion with his hand that his sons interpreted as a request for another betel nut. So began several hours of communicating with gestures.

Ponram seemed dazed, but slowly his eyes began to focus on people and objects. For a while he stared at his hand. Someone made a commotion in the crowd, provoking immediate shouts of 'Hush, quiet'. It looked like word had spread that something significant was happening because people kept packing into the house, squeezing into places to sit on the already crowded floor. After opening and closing his hand several times, Ponram counted his fingers. The medical assistant explained that he was counting his sons. Someone else suggested that he was calling for those sons who were on Ndropwa. Sayau Bombowai did most of the translating, while others in the crowd occasionally made suggestions. Pantret, the kaunsil of Lowaya, moved close to Schwartz to translate for him from Titan, in which Schwartz was still a novice, and from scraps of Usiai languages to Tok Pisin. Sayau Bombowai began to question Ponram, using gestures like those Ponram was using, which were much like those used by a local deaf mute. Ponram was sitting up now, gesturing more vigorously and dramatically. Everyone seemed to know just what was happening, what to do, and how to translate, as if they had seen it all before. Sometimes Ponram would repeat a gesture until someone in the audience caught on and interpreted it aloud. Then Ponram would turn towards that person and smile. To an American, it resembled a game of charades. 
Stretching his arms over his head, Ponram indicated — as Pantret translated for Schwartz - that he had been to Heaven. He had died as a punishment for his wrongdoing and had been brought to God. Now he had been sent back to report the many things revealed to him. He began to recite, using gestures, all the sins that he had ever committed. He had beaten his wife and children repeatedly and, when a child, he had stolen. He indicated that his son, Poteri, should stand up, then he acted out the message that one woman should not have two men. (Poteri was living with a woman in the same house with her aged husband, with the husband's consent.) Then Ponram spoke in gestures against divorce. He continued to pronounce against all the things so often condemned in the New Way. Although everyone had heard all this almost daily since the start of the Movement, it now came to them as direct divine revelation and they listened intently.

Ponram handed a shirt to two of his sons, instructing them to suspend it between them while he pretended to write on it, although it was well known that he was illiterate. As he pretended to write he shook his head approvingly. He next mentioned some of the people he had seen in Heaven. Sayau Bombowai and the people in the crowd interpreted his gestures through trial and error, guessing until Ponram indicated they had found the right name. But it also appeared that many were familiar with the larger story on which he was embarking. Ponram pantomimed putting on trousers, which the crowd took to mean 'I am an old man. I wear trousers and a shirt, while you young men wear laplap', although Ponram was actually wearing a laplap. He called for an enamel plate, showed that it was clean, and beamed his approval. He made motions as if eating with a spoon, indicating that this is good. He called for an old wooden bowl, threw it to the floor indicating that this was bad, for it was something of the past.

By this time, Ponram seemed fully awake, fully alert-although still unable to speak-and thoroughly enjoying being the centre of attention. He soon began to whistle an accompaniment to his gestures. The whistles were like the ones mediums used in seances to communicate with ghostly household guardians, which villagers had demonstrated for Schwartz previously. Continuing his account of revelations, Ponram kept looking about for props. He picked up a piece of cooked taro, took several bites, and spat each one out in disgust. This kind of food was no good, he thus indicated. Then he took up the enamel plate again in approval, indicating that only European foods were good. He took hold of the nipple of his breast, shaking his head approvingly, then again spat out taro, which the 
crowd took to mean that the common practice of women feeding children with pre-masticated taro was no good, they should feed them with the breast alone; taro and sago are fit only for pigs and dogs. For each point in a long list of contrasts, people in the crowd exclaimed 'tru?' - Tok Pisin for true-or 'nru konan!' - meaning true in Ponram's Usiai language.

The audience was more relaxed by this point and occasionally amused by Ponram's pantomimes. He continued to condemn all things indigenous and to praise all things European. He listed again everything he had done that was wrong (omitting several recent misdeeds for which he had been brought to court). He tore a scrap off a piece of newspaper for each sin and gave all the slips to the medical assistant. (In many parts of rural Papua New Guinea, people have long used newspaper for rolling cigarettes, hence its availability during these 1954 events.) He began to use Schwartz as a prop. He pointed to Schwartz's watch, making the 'plenti, plenti' gesture a local deaf mute used when describing the wealth of the American army during the war.

Ponram eventually began to lose the audience's undivided attention, but he recaptured it when he began to construct a model of the gate to Heaven out of firewood. Here the Johnston Island cemetery came to mind again. Ponram said that he had been told to urge people to build a new cemetery for Bunai. The door that he modelled from sticks had a turnstile in it, like those each village gate had sported during the early part of the Movement. This finished, he seemed to run out of ideas and repeated much of what he had already done. As a variation, he called for his wife, whom he had just confessed to beating. He had her sit beside him. Taking the plate, he pretended to feed her with a spoon and he raised a cup to her lips, pretending to give her tea, while she very seriously pretended to eat and sip. This was the New Way model for the husband and wife, sitting together to eat as Europeans do. As the repetitious lecture continued, he again lost the crowd's attention. He then began to make noises with his mouth, as if speech were returning. The crowd again closed in around him, eager and expectant, as if they knew what was coming. He began to speak very rapidly in his Usiai language. His voice was a high-pitched falsetto. He repeated orally everything he had just acted out silently. His discourse took on the highly stylised form of New Way speeches. He recited long lists of formulas for all the virtues and vices approved or condemned in the New Way. At last, at about 2:30 in the afternoon, he lay back exhausted. The crowd dispersed. 
Word of Ponram's death, vision, and resurrection spread through Bunai, to other villages along the south coast, and to Baluan. For months afterwards, orators at meetings used Ponram's death and resurrection as a warning to sceptics. For instance, Kampo of Lahan, in a speech berating the rank and file for their laxity and indifference to New Way leaders, proclaimed that the sceptics who said that they wanted to see Christ with their own eyes and hear him with their own ears should look at Ponram and be convinced. They might otherwise be taken to see Christ as Ponram had been taken to Heaven and perhaps not return.

Observing Ponram's resurrection helped Schwartz to understand a number of superficially unrelated events. For instance, Kampo of Lahan had allowed Schwartz to examine a journal he kept of outstanding events in which he had figured since the Lahan people's move to the beach. Here is Schwartz's summary of an entry for 17 September 1949:

Kampo had quarrelled with his wife, Nambuleo. The next day, they went to present their grievances against each other to the government officer at Patusi Patrol Post. When they stopped to rest at a house on their way back to Bunai, Nambuleo suddenly collapsed, seemingly lifeless. Not until the following morning, back in her own village, did she regain consciousness, though she could neither hear nor speak. Her eyes were closed, but she ate, smoked, and walked about outside. She did not return to normal for two more days. Towards the end of her seizure she was able to explain that she had died and her tingting had gone to Heaven. When she came out of the house, she looked to the interior of the island, noting how rough and hilly the terrain was, and said that all this was no good. In Heaven the ground was perfectly flat, with a long, broad, clear road. All the houses were in perfect lines. There was no hard work carrying things. Anything you wanted, you had only to think and it was there. It was not even necessary to eat; if you were hungry, you just thought and your belly was filled. You had only to think and you were sitting in a car. You didn't have to climb into it. She saw people that she knew who had died. When she wanted to shake their hands, they said, 'Wait, you go straight to God first'. When she saw God, he wasn't sitting on something, he was just there. God asked her, 'What did you come here for?' She said, 'I don't know'. God told her: 'You must go back. You must change your ways-your stubbornness, your lying, your disobedience. If you don't I will bring you back here for good'. Then she saw her mother, father, and sister. She shook hands with them. Then she returned. Kampo added that Sayau 
Bombowai's wife had died and returned shortly before his own wife's experience. He said: 'It was like what had happened to many people during the Noise. It happens occasionally, as a warning'.

Two months before Ponram's resurrection, Schwartz and Shargo had been involved in another event they initially took at face value. An elderly Usiai man of Yiru village, Jakob, had been fishing in the shallow lagoon at night. Schwartz and Shargo were called to see him when he was reported to be dying from the bite of a poisonous sea creature. His condition was roughly like Ponram's-limp paralysis, loss of speech and hearing, followed by gradual recovery within the next hour. People said that a sea snake had bitten him. Later he said it had been a crab, though it had not broken the skin. A house full of spectators carefully and sympathetically attended to his gestures and words as he came to consciousness. He was convinced that he was dying, that his throat was closed, and that he could neither eat nor drink. He communicated at first with his hands, later in weak and garbled speech. He went through a repertoire of revelations confirming New Way principles. His made a special point of cautioning people about the dangers of the sea. He said that the children should not be allowed to go into the water. His total recovery took about the same time as Ponram's, as his children spoon-fed him.

For some time afterward, people treated Jakob with unusual respect, but he elicited much less attention than Ponram. He was also less transformed by his experience than was Ponram, in whom the ready response of his audience produced a quick expansion of his personality as he moved into the role of righteous messenger, which for him was a novel guise. In fact, both he and Jakob were known as troublemakers. Most recently, Ponram had been brought into court for urging his sons to thrash the husband of his adopted daughter, and Jakob had instigated a quarrel that almost split his hamlet. Ponram in particular, however, took advantage of his experience to change his image. He had always worn a laplap in the past, but now he began to wear European clothing. He began to attend village meetings regularly, where people received with respect his pious but totally unoriginal speeches. He also lent his moral weight to the cemetery project.

Still naive, Schwartz found these deaths and resurrections worthy of close attention, but he regarded them as idiosyncratic expressions of the continued vitality of Noise ideology and the degree to which it had become an accepted part of local Christianity. He was mistaken. The dramatic events and the interest they aroused were part of an extant cargo cult of which he and Shargo were still unaware. 


\section{Schisms and secrets}

Shortly thereafter, Schwartz left Bunai to visit Ndrano, an Usiai village in the interior. The route inland began in the coastal Titan village of Patusi. In Patusi, he noticed open hostility between the Patusi Titan and people of the two Usiai villages_-Nuang and Kapo-that, under the influence of the New Way, had relocated contiguous to Patusi. In Ndrano, he saw further evidence of old schisms returning and new ones emerging. Several older Ndrano men were conducting pre-New Way style ceremonial exchanges. Younger Ndrano men looking on made a great display of their disinterest. Schwartz had been told in Bunai that many interior people still practised what they called in Tok Pisin sting pasin bilong bipo-the rotten (or stinking) ways of the past-and these young Ndrano men seemed to hold the work of their elders in similar contempt. Yet other Ndrano men jeered the Bunai Usiai accompanying Schwartz-people who had given up the stinking ways of the past-for having become no better than the Titan. Schwartz's Bunai Usiai companions adopted expressions of quiet contempt for the taunts.

Returning from Ndrano to Bunai, Schwartz found the atmosphere there unusually tense. People with whom he had enjoyed relaxed relationships had become reserved and distant. The Usiai who had called Schwartz and Shargo to come to meetings in their sections of the village no longer did so. Conflict between Titan leaders like Samol and Tjamilo and some of the Usiai leaders had sharpened.

Throughout this period, Schwartz and Shargo continued reconstructing the 1947 Noise. Later, however, they found that some attitudes and behaviour they took as echoes of the past were in fact symptoms of friction over the Cemetery Cult, of which they were still naively unaware. Without any obvious provocation, village meetings were now full of highly emotional speeches invoking God and Jesus and condemning a decline in morale, morals, and social cohesion. People spoke with great passion of building a new graveyard. This sounded like a modest project logistically, but people used every conceivable argument and rhetorical device to support or oppose the proposal. Some made lengthy speeches condemning themselves and others for not heeding the leaders, not attending church, and neglecting to repair their houses, mixing such criticisms with lavish allusions to the golden years in the Movement's youth when people had done things properly. During most of their stay to 
this time, Schwartz and Shargo had heard scarcely anything of the 'Long Story of God' in public settings, even in church services, but now people referred to it often in meetings on matters of all kinds.

Despite the intense emotion displayed, many speakers sounded demoralised. One after another declared, in Tok Pisin, that the village was rong finis - that is, completely wrong. The administration had again postponed initiating a Native Government Council beyond the Baluan Council area, and it came to light that leaders of the existing ad hoc assembly of Movement kaunsil had helped themselves to some of its funds. Movement leaders from the south coast and southerly islands met to discuss the funds collected in the early days of the Movement and argue about their disposition. The money had originally been collected in 1947-50, and each village had agreed that it would not ask for the return of its contribution. The fund was placed at Paliau's disposal to buy whatever he thought best for the Movement. Many of his followers agreed that the Movement should use the money to buy a boat. The administration, however, tried to persuade the Movement leaders to return the funds to the individual donors and insisted on taking control of the money on behalf of the donors.

Now, in meetings in Bunai, one leader after another leader said that the people of his village wanted the money redistributed. Paliau's prestige was also at stake. In a decisive meeting, a speaker said that when the money was entrusted to Paliau they had all been like children; now, they were grown up and no longer needed such paternalistic care. Finally, those assembled decided to allow Paliau to determine the disposition. But Paliau refused to make the decision for them. So the question remained unresolved and the tensions it aroused lingered.

At the same time, Schwartz sensed that Tjamilo and some of the Usiai seemed to be trying to control their excitement about something. But it was something of which they would not speak to Schwartz, for almost overnight they had become decidedly reserved, almost hostile. Kampo of Lahan, with whom Schwartz had been on good terms, seemed disturbed and conflicted about something, but he was now keeping his distance from Schwartz. Here is a passage, translated from Tok Pisin, of a speech Kampo gave at a meeting in Lahan on 4 March 1954:

We must take good care of the dead. Jesus has spoken. Eventually they will all arise. All our people whom we have lost, do you think you will see them? The masta and misis [Kampo used these thencommon terms of address for male and female Europeans to refer 
to Schwartz and Shargo], they will outlive all of us. They will grow old and we will die. You must take good care of all who have died. Make a fence, a cemetery. With them [the dead] also it is the same. They cry to us about all our bad ways. 'Now we want to come to you. We already have attained the good life. We want to arise again, but you block our path with your evil ways.' God is very close to us. To whomever doesn't believe, he will make a sign so that you will see him truly ... We talk all the time about material things, but some of the time we must think about God who made us.

Of all the speeches made at open public meetings in this period, this one contained the most overt references to belief in the return of the dead, part of the ideology of the cargo cult soon to come out in the open. Kampo was unaccountably depressed and withdrawn in the weeks surrounding this meeting. He spent a lot of time with Schwartz and Shargo, apparently absorbed in work on wood carvings he was making for them. But he did not speak of the things troubling him.

Many speeches at public meetings were full of the phrase 'we must return to the ways of 1946'. The ever more apparent hostility between the Titan and the Usiai was matched by the increasing frequency of speeches about brotherhood, the need for mutual compassion and generosity (in Tok Pisin, maremare), and warnings that the village was full of bad feelings that should be exorcised. No one disapproved of such statements. But in a way Schwartz did not fully understand, Titan people seemed to feel the Usiai were attacking them. The Usiai implied they were the leaders of a new moral revival. They were particularly aggressive in calling for rectification of a grievance that, in their eyes, was disturbing communal harmony more than any other-disagreement about the ownership of the land on which the village was situated. The Titan people of the villages of Tjalalo, Ndropwa, and Pomatjau claimed the land. But the Usiai of Pwa and Lesei, once autonomous villages that had been incorporated into Lowaya, had long contested these Titan assertions, taking their claim to one foreign government officer after another-German, Australian, even Japanese. Kisekup, the paramount luluai for the region, was an expert in such matters. He had been highly skilled in dealing with administration officers and had successfully defended the Titan claim to the land several times. This even though the Titan admitted among themselves, and sometimes even to Usiai people, that it was really Usiai land. 
The question, however, was never simple. The Titan often gathered coconuts and forest materials from the area and cut sago palms there. And in the eyes of the administration, the Titan owned it. When the Usiai moved to the beach, the Titan had welcomed them. As the administration saw it, Titan had allowed them not only use of land for houses on the beach but use of the nearby land in question. According to the communal principles of the Movement, people were to freely grant others use of land or other resources, but this did not entail change in ownership. So, the Bunai Usiai were demanding that the spirit of brotherhood required the Titan to rectify their false claim to the land and declare themselves once more landless.

Eventually, in the name of the New Way, Kisekup and other Titan elders conceded Usiai ownership. The Titan, however, said that it did not really matter because since the beginning of the Movement they had had no thought of either individual or group landownership within the Movement community. The Usiai disputants also said that it did not matter, that they also had no thought of exclusive ownership. Even so, they wanted the Titan concession of Usiai ownership entered in the books of the government as soon as possible. The resolution required a mass handshaking ceremony. The Usiai formed two long lines in order of size, from the adults down to the smallest children who could stand alone. The Titan also formed a long line, which then moved along the front line of Usiai, then turned and went back down the second line until each Titan man, woman, and child had shaken the hand of each Usiai man, woman, and child.

That painfully won settlement, however, did not stop the procession of public meetings about other matters, some apparently mundane but that Schwartz still found opaque. Listening to hour after hour of discussion and debate, Schwartz noticed people beginning their orations more and more often with long distributive formulas of address. In an extreme example, one speaker addressed his speech to 'you, all children, women, men, mother, father, brother, sister, young men, young women, old men, old women, you altogether, you must listen'. Speakers hammered the theme of equality and universal participation in community life. Finally, in a speech ending one meeting, Petrus Popu of Lowaya reviewed the history of the Movement. In concluding, he said that in 1946 everything had been right, but now everything was wrong. He said that 1950 had been the turning point, when things had begun to go awry. He attributed 
this to lapsing from the purity of 1946 and to people's fear of the whites, particularly the one or two kiap who had made it their mission to break the Paliau Movement.

Schwartz and Shargo were coming to understand that by the time they arrived in Manus in 1953, people accepted 1946 as shorthand not only for the period of Movement growth and excitement preceding the Noise, but also for the events of the Noise itself and the more ritualistic practices of the post-Noise Movement extending up to 1949. The year 1950 had become the accepted date for the Movement version of the Fall, an analogy many orators invoked. There is scarcely an entry in the notes Schwartz and Shargo took from February through March 1954 that does not make more sense if read with an understanding that such references were evidence that a cargo cult was building momentum. Adherents were keeping this secret not only from Shargo, Schwartz, and Mead, but also from some within the Movement from whom they expected opposition. Adherents even excluded some who would have liked to be included in the cult. Much of the sharpening conflict between Tjamilo and Samol, it eventually became clear, came from their competition for leadership in the cult.

As Paliau and his lieutenants had done successfully at the beginning of the Movement, adherents of the Cemetery Cult used secrecy and exclusion to recruit new comrades. As the secrecy became more conspicuous, the cult finally became visible to the anthropologists, although only through what appeared to be an accident did they acquire more intimate access and knowledge. Such accidents, however, were by this time almost inevitable. Schwartz and Shargo had become an important audience and to some extent the cult needed them.

While all this was going on, Schwartz was studying the older Usiai culture, which required consulting Usiai memories, for Mead and Fortune had given the Usiai little attention. Schwartz had been recording the oldest Usiai men's accounts of past events. But as cult activity increased, he began to have difficulty finding willing collaborators. Several men from Lowaya who had agreed to help him failed repeatedly to show up. When he went to Lowaya to find them, he happened on a meeting in a house far from the main route to the village. Everyone in Lowaya seemed to be crowded into the house, and Schwartz noticed immediately that his presence embarrassed people. He eventually found the men he was seeking, and they promised to come to his house. Schwartz, seeing that 
he was not wanted, left, expecting to see the men later. But, once again, they didn't show. Walking home, he had passed several Usiai men with whom he had been working closely. But instead of greeting him as usual they turned their eyes away. Among them was Petrus Popu, his main Usiai collaborator, and Pondis of Malei, who had accompanied him on a trip into the interior and who had spent a great deal of time in Schwartz and Shargo's house.

\section{The light goes on}

On 22 March 1954, Schwartz and Shargo finally learned why the social atmosphere was changing. That evening, Schwartz had planned to continue delving into the Usiai past, but his collaborators again failed to appear. The night was brilliantly moonlit so he decided to walk to Lahan to look for them. When he got there a meeting was in progress and Kampo was addressing visitors from the north coast Usiai village of Lowa. Kampo was making long tutorial statements about the principles of the New Way to people who had heard it all innumerable times. Over and over he said: 'There is nothing that just materialises; everything comes from hard work'.

Schwartz had heard all this many times already, so he decided to go on to Lowaya, to look for his usual helpers there, but they were absent. It was near midnight when he returned home through Malei, which was not far from his and Shargo's house. He noticed that everyone in Malei was still awake and fully dressed in their best clothing. Reaching home, he found Kampo Monrai, an adolescent man of Malei, talking to Shargo, who was listening, rapt. Earlier, while she had been walking towards Malei, Kampo Monrai had seen her and approached her to ask: 'Did you hear the whistles?' Something in his voice suggested she should answer 'Yes' instead of 'What whistles?' It was the 'mark' (Tok Pisin, mak, meaning sign) on Malei, said Kampo. The whistling of the dead had been everywhere in Malei the previous night and it was continuing tonight. The mark was on Pulu Nrabokwi's wife and everyone was very excited. Shargo allowed Kampo Monrai to believe that she knew all about this, but invited him to come back to the house to talk about it. There, in a recorded conversation, she obtained the anthropologists' first explicit descriptions of the cult. Ghostly revelations rather than dreams and visions guided it, but it was virtually the same as the Noise in its fundamental doctrines. Thus, Schwartz and 
Shargo came to understand that there was a more-or-less constant current of cult hope and belief that was now resurfacing in a slightly different form. Manus people themselves christened the cult of 1947 the Noise, after the shaking that affected its adherents. We have been calling this second manifestation the Cemetery Cult and will continue to do so, but even its most ardent adherents had no single name for it.

Now that they knew what lay beneath the surface of the many puzzling events they had witnessed and the troubling changes in people's attitudes towards them, Schwartz and Shargo undertook a more focused investigation. The next chapter recounts what they found through direct observation of events and dozens of interviews with the principal figures. 
This text is taken from Like Fire: The Paliau Movement and Millenarianism in Melanesia, by Theodore Schwartz and Michael French Smith, published 2021 by ANU Press, The Australian National University, Canberra, Australia.

doi.org/10.22459/LF.2021.08 